\title{
COVALENT BINDING OF ETHINYLESTRADIOL AND ESTRONE TO RAT LIVER DNA IN VIVO
}

\section{WALTER JAGGI, WERNER K. LUTZ and CHRISTIAN SCHLATTER}

Institute of Toxicology, Federal Institute of Technology and University of Zurich, CH-8603 Schwerzenbach (Switzerland)

(Received February 2nd, 1978)

(Revision received May 12th, 1978)

(Accepted May 22nd, 1978)

\section{SUMMARY}

The covalent binding of $\left[6,7-{ }^{3} \mathrm{H}\right]$ ethinylestradiol (EE) and $\left[6,7-{ }^{3} \mathrm{H}\right]$ estrone (E) to liver DNA of $200 \mathrm{~g}$ female rats was measured $8 \mathrm{~h}$ after the administration of $80 \mu \mathrm{g}(9.2 \mathrm{mCi})$ estrogen by gavage. The binding is 1.5 for $\mathrm{EE}$ and 1.1 for $\mathrm{E}$, expressed as binding to DNA/dose, in units of $\mu \mathrm{mol}$ hormone $/ \mathrm{mol}$ DNA phosphate/mmole hormone/kg body wt. It is in the same order of magnitude as for benzene and about 10000 times below the binding of typical liver carcinogens, such as aflatoxin $\mathrm{B}_{1}$ or $N, N$-dimethylnitrosamine.

\section{INTRODUCTION}

Since 1973, several reports indicate that adenomas of the liver may occur in women taking oral contraceptives [1], and long-term toxicity studies in the beagle have shown that the administration of synthetic progestogens resulted in a range of mammary lesions [2]. There is no agreement as to the mechanisms whereby these steroids induce such lesions, or whether the lesions found with the beagle are important in assessing the potential safety of a compound for use in other species, such as humans. The hormonal activity of the compounds in question interacts closely with other endocrine secretions so that it is difficult to dissociate the effects of the hormones themselves from the secondary effects of other agents.

In the process of the chemical induction of a tumor, binding of that chemical or one of its metabolites to a biological macromolecule seems to be the first step $[3,4]$. Good correlations between that binding and carcino-

Abbreviations: E, estrone; EE, ethinylestradiol. 
genicity have been found with DNA as target molecules rather than with RNA or protein $[5,6]$. A binding of ethinylestradiol and other hormones to protein has been measured in vitro and in vivo $[7,8]$ but a binding to nucleic acids was detected only in vitro [9-11].

Our laboratory has specialized in detecting the binding of weak and suspect carcinogens to DNA in vivo $[12,13]$, and in this paper we report our positive findings with tritiated ethinylestradiol (EE) and estrone (E).

6,7-tritiated estrogens urere used, because 6 and 7 are relatively inert positions in the metabolism [7] and a binding to DNA in the presence of rat liver microsomes occured with a retention of that label [11].

\section{MATERIALS AND METHODS}

Materials

Reagents without specified distributor were of the highest purity available from Merck, Darmstadt, FRG.

$\left[6,7{ }^{3} \mathrm{H}\right]-\mathrm{E}$ was radiosynthesized by reducing 6 -dehydroestrone (3-hydroxy-1,3,5(10),6estratetraen-17-one, $0.154 \mathrm{mmol}$, Steraloids Inc. Wilton, N.H.) according to Merrill and Vernice [14] with $0.14 \mathrm{mmol}$ carrierfree tritium gas ( $8 \mathrm{Ci}$, The Radiochemical Centre, Amersham, U.K.) in $1 \mathrm{ml}$ ethyl acetate containing $25.6 \mathrm{mg} 10 \% \mathrm{Pd} / \mathrm{C}$ catalyst (Fluka AG, Buchs, Switzerland). After $3 \mathrm{~h}$, the remaining educt was reduced with $0.19 \mathrm{mmol}$ hydrogen gas.

$\left[6,7 .{ }^{3} \mathrm{H}\right]-\mathrm{EE}$ was prepared by treating $17.9 \mathrm{mg}$ tritiated $\mathrm{E}$ with $38.2 \mathrm{mg}$ lithiumacetylide (Lithiumacetylid-Aethylendiaminkomplex pract., Fluka $A G)$ and separated from the $E$ after treatment with $15.4 \mathrm{mg}$ Girard's reagent $P$ (Fluka AG) according to Cooley and Harris (15).

Purification: Immediately before use, the radioactive hormones were chromatographed preparatively on silica gel thin layers (DC Alufolien Kieselgel $60 \mathrm{~F}_{254}, 0.2 \mathrm{~mm}$, Merck) with chloroform/ethyl acetate, $4: 1$. The hormones were eluted from the appropriate locations (as compared with inactive hormones from Serva, Heidelberg, FRG) with ethanol and ether. The solvent was blown off with nitrogen and the hormone was redissolved in $1 \mathrm{ml}$ ethanol, fractions of which were administered to the rats by gavage. Control fractions were used for the determination of the specific activity and were rechromatographed. The radiochemical purity was found to be better than $98.8 \%$ for EE $(0.6 \%$ were $\mathrm{E})$ and $99.6 \%$ for $\mathrm{E}$. The specific activity of these compounds was $32.5 \mathrm{Ci} / \mathrm{mmol}$ as measured from liquid scintillation counting in a BF 5000 counter (Berthold, Wildbad, FRG) and UV analysis [16].

\section{Animals}

Female rats (SIV-50, Sprague-Dawley-derived) were obtained from the Kantonales Tierspital, Zürich, Switzerland. They were fasted the night 
TABLE I

INCORPORATION OF RADIOACTIVITY INTO LIVER DNA OF 4 FEMALE RATS, 8 H AFTER A GAVAGE OF TRITIATED STEROID HORMONE

\begin{tabular}{|c|c|c|c|c|c|}
\hline \multirow[b]{2}{*}{ Dose administered } & \multirow[b]{2}{*}{$\begin{array}{l}\mu \mathrm{g} \\
\mathrm{mCi} \\
\mathrm{mmol} / \mathrm{kg}\end{array}$} & \multicolumn{2}{|l|}{$\mathbf{E E}$} & \multicolumn{2}{|l|}{$\mathbf{E}$} \\
\hline & & $\begin{array}{l}79 \\
8.7 \\
0.00139\end{array}$ & $\begin{array}{l}91 \\
10.0 \\
0.00154\end{array}$ & $\begin{array}{l}56 \\
6.7 \\
0.00087\end{array}$ & $\begin{array}{l}94 \\
11.3 \\
0.00145\end{array}$ \\
\hline DNA isolated & $\begin{array}{l}\mathrm{mg} \\
\text { gross cpm } \\
\mu \mathrm{mol} / \mathrm{molDNA} \text { P }\end{array}$ & $\begin{array}{l}3.3 \\
296 \\
1.86 \cdot 10^{-3}\end{array}$ & $\begin{array}{l}3.7 \\
441 \\
2.55 \cdot 10^{-3}\end{array}$ & $\begin{array}{l}7.1 \\
278 \\
8.18 \cdot 10^{-4}\end{array}$ & $\begin{array}{l}7.3 \\
605 \\
1.79 \cdot 10^{-3}\end{array}$ \\
\hline Binding index & $\frac{\mu \mathrm{mol} / \mathrm{mol} \text { DNA P }}{\text { mmol } / \mathrm{kg}}$ & 1.34 & 1.65 & 0.94 & 1.24 \\
\hline
\end{tabular}

before treatment but had free access to drinking water. The weight ranged from 190-240 g. At 11:00 h, the hormone was administered with dose and radioactivity as given in Table $\mathrm{I}$. The animals were held in open metabolism cages for the collection of urine. After $6 \mathrm{~h}$, they were given $5 \mathrm{ml}$ tap water by gavage in order to increase urine production. At 19:00 h, the animals were killed by stunning and cervical dislocation, were bled by heart puncture and the liver was excised.

\section{Isolation of DNA.}

DNA was purified according to Markov and Ivanov [17] and redissolved in $4 \mathrm{ml} 0.014 \mathrm{M}$ sodium phosphate buffer, $\mathrm{pH} 6.8$. An aliquot was diluted for UV analysis and the bulk quantity was mixed with $10 \mathrm{ml}$ Insta-Gel (Packard, Downers Grove, Ill.) for liquid scintillation counting. The amount of DNA was determined by assuming an absorbance of 190 for a 1\% solution at $260 \mathrm{~nm}$. The absorbance ratio $260 \mathrm{~nm} / 230 \mathrm{~nm}$ was better than 2.27 in all DNA samples so that a maximal protein contamination of $0.1 \%$ can be expected [17].

\section{Control experiments.}

Background radioactivity of DNA was measured from a rat which was held in parallel to the treated ones. The gross count amounted to $21.7 \pm 0.6$ cpm from 2.5 mg DNA.

Non-enzymatic binding of the hormones to DNA was checked by incubating $3 \mathrm{~g}$ of liver, homogenized and denatured in $25 \mathrm{ml}$ lysing medium $(0.24$ $M$ sodium phosphate, $\mathrm{pH} 6.8,8 \mathrm{M}$ urea, $0.01 \mathrm{M}$ EDTA, $1 \%$ sodium dodecyl sulfate) with $2.7 \mathrm{mCi}$ hormone for $4 \mathrm{~h}$ at room temperature. The net count after isolation of that DNA was $12 \mathrm{cpm}$ from $\mathrm{EE}$ and from $\mathrm{E}$.

Incorporation of tritium from tritiated water (HTO) into liver DNA was 
determined $12 \mathrm{~h}$ after administrating $10 \mathrm{mCi} \mathrm{HTO} / \mathrm{kg}$ to control rats by stomach tube. The specific radioactivity amounted to $21 \mathrm{dpm} / \mathrm{mg}$ DNA.

\section{RESULTS}

Table I summarizes the experiments performed on the binding of tritiated $\mathrm{EE}$ and $\mathrm{E}$ to rat liver DNA, $8 \mathrm{~h}$ after oral administration of the hormone.

The control experiment on non-enzymatic incorporation of radioactivity into DNA showed that the radioactivity recovered from the main experiments must be covalently bound. Such a binding can occur from a hormone molecule, one of its metabolites or from the incorporation of tritium from tritiated water. Water could be formed by metabolic oxidation of the tritiated carbon atoms 6 or 7 , or by the release of a tritium atom during the radioactive decay of its neighbor. Analysis of the urine collected after the administration of the hormones showed that from EE only $1 \%$ of the total radioactivity was excreted in the 8 -h urine. Four percent of that radioactivity lyophilized as tritiated water. With estrone, the corresponding figures were $3 \%$ excreted, $3 \%$ of which was tritiated water. The specific activity of water in urine was therefore in the order of $10^{6} \mathrm{dpm} / \mathrm{ml}$, and we can assume that the total body water had a similar specific activity. The control experiments on the incorporation of tritium from tritiated water into DNA were performed with a specific activity of the body water of about $3 \cdot 10^{7} \mathrm{dpm} / \mathrm{ml}$. The corresponding specific activity in the hormone experiments was thirty times lower so that, theoretically, less than 0.7 $\mathrm{dpm} / \mathrm{mg}$ DNA could be due to that mode of DNA labelling. This is so little as compared to the specific activity of DNA from the main experiment that our binding values must represent the labelling of DNA with a hormone derivative.

\section{DISCUSSION}

We have demonstrated a covalent binding of $E E$ and $E$ to rat liver DNA in vivo. Carcinogenic activities of these - and probably other - estrogens could therefore be based also upon their chemical reactivity towards nucleic acids and do not necessarily depend upon the hormonal activity. The introduction of the ethinyl substituent into the naturally occurring estrone enhances the binding capacity slightly, probably due to the fact that the metabolic degradation at position 16 is slower in the case of the synthetic analogue and leads to an increased formation of other, chemically more reactive, metabolites. This is in agreement with the in vitro experiments [7] where the binding of EE to protein is about twice that of estradiol.

The binding index found with the hormones is similar to that of benzene (1.7, see ref. 12), but about 4 orders of magnitude below those of typical liver carcinogens such as aflatoxin $B_{1}$ [18] or $N, N$-dimethylnitrosamine [19]. For a comparison of different chemicals the binding index gives the number of molecules which are bound to DNA from an administration of 
a unit dose of $1 \mathrm{mmol} / \mathrm{kg}$. If the binding from a specific exposure has to be estimated, e.g. for a risk assessment, the effective dose of that specific chemical to which an individual is exposed must also be accounted for. Typical exposures to benzene which eventually lead to leukemia in humans amount to grams/day [20]. The exposure to $\mathrm{EE}$ as a contraceptive, on the other hand, is only about $50 \mu \mathrm{g} /$ day.

The damage expected from the natural estrogens is similar to the one found from the use of the ethinyl derivative: A woman produces an average of a few $100 \mu \mathrm{g} /$ day while towards the end of a pregnancy, this production increases by more than a factor of 100 .

This quantitative discussion of binding and presumptive carcinogenic risk is still very tentative. Additional data are required on the mutagenic potency of a specific type of damage to the DNA as well as a measure of the repair of the DNA in the target organ. Nevertheless, EE and E should be equal in this respect so that on the basis of our findings we can deduce that $\mathbf{E}$ and its ethinyl derivative should not differ much with regards to a suspected chemical carcinogenicity.

\section{REFERENCES}

1 H.A. Edmondson, B. Henderson and B. Benton, Liver-cell adenomas associated with use of oral contraceptives, New Engl. J. Med,, 294 (1976) 470.

2 M. Briggs, The beagle dog and contraceptive steroids, Life Sci., 21 (1977) 275.

3 J.A. Miller, Carcinogenesis by chemicals: an overview. G.H.A. Clowes memorial lecture, Cancer Res., 30 (1970) 559.

4 P.N. Magee, A.E. Pegg and P.F. Swann, Molecular mechanisms of chemical carcinogenesis, in: Handbuch der allgemeinen Pathologie vol. VI/6, Springer, Berlin, 1975, p. 329.

5 P. Brookes and P.D. Lawley, Evidence for the binding of polynuclear aromatic hydrocarbons to nucleic acids of mouse skin: relation between carcinogenic power of hydrocarbons and their binding to deoxyribonucleic acid, Nature (Lond.), 202 (1974) 781 .

6 E. Huberman and L. Sachs, DNA binding and its relationship to carcinogenesis by different polycyclic hydrocarbons, Int. J. Cancer, 19 (1977) 122.

7 H.M. Bolt, H. Kappus and R. Kasbohrer, Metabolism of $17 \alpha$-thinylestradiol by human liver microsomes in vitro: Aromatic hydroxylation and irreversible protein binding of metabolites, J. Clin. Endocrinol. Metab., 39 (1974) 1072.

8 H. Kappus, H.M. Bolt and H. Remmer, Irreversible protein binding of metabolites of ethinylestradiol in vivo and in vitro, Steroids, 22 (1973) 203.

9 H.M. Bolt and H. Kappus, Irreversible binding of ethinylestradiol metabolites to protein and nucleic acids as catalyzed by rat liver microsomes and mushroom tyrosinase, J. Steroid Biochem., 5 (1974) 179.

10 J.C.M. Tsibris and P.M. McGuire, Microsomal activation of estrogens and binding to nucleic acids and proteins, Biochem. Biophys. Res, Commun., 78 (1977) 411.

11 G.M. Blackburn, L. Orgee and G.M. Williams, Oxidative bonding of natural oestrogens to DNA by chemical and metabolic means, J.C.S. Chem. Comm., 1977 No. 11 386.

12 W.K. Lutz and Ch. Schlatter, Mechanism of the carcinogenic action of benzene: irreversible binding to rat liver DNA, Chem.-biol. Interact., 18 (1977) 241.

13 W.K. Lutz and Ch. Schlatter, Saccharin does not bind to DNA of liver or bladder in the rat, Chem.-biol. Interact., 19 (1977) 253. 
14 E.J. Merrill and G.G. Vernice, Synthesis of $17 \alpha$-ethinylestradiol- $6,7-{ }^{3} \mathrm{H}$ and $17 \alpha$-ethinylestradiol-6,7-3 H-3-cyclopentyl-1-14 C-ether, J. Labelled Compds., 6 (1970) 266.

15 G. Cooley and I.A. Harris, Preparation of ethinyloestradiol $-4 \cdot{ }^{14} \mathrm{C}$, J. Labelled Compds., 5 (1969) 8.

16 E.G.C. Clarke (ed.), Isolation and identification of drugs, The Pharmaceutical Press, London, 1969, pp. 335 \& 454.

17 G.G. Markov and I.G. Ivanov, Hydroxyapatite column chromatography in procedures for isolation of purified DNA, Anal. Biochem., 59 (1974) 555.

18 D.H. Swenson, J.-K. Lin, E.C. Miller and J.A. Miller, Aflatoxin $B_{1}-2 ; 3-0 x i d e$ as a probable intermediate in the covalent binding of aflatoxin $B_{1}$ and $B_{2}$ to rat liver DNA and ribosomal RNA in vivo, Cancer Res., 37 (1977) 172.

19 P.J. O'Connor, M.J. Capps and A.W. Craig, Comparative studies on the hepatocarcinogen $N, N$-dimethylnitrosamine in vivo: reaction sites in rat liver DNA and the significance of their relative stabilities, Br. J. Cancer, 27 (1973) 153.

20 E.C. Vigliani, Leukemia associated with benzene exposure, Ann. New York Acad. Sci., 271 (1976) 143. 